\title{
Uji Kinerja Aplikator Pupuk Organik Dan Pengaruh Bahan Organik Terhadap Sifat Fisik Tanah Dan Pertumbuhan Tanaman Melon (Cucumis melo L.)
}

\author{
Hartono $^{1}$, Iqbal ${ }^{1}$ dan Daniel ${ }^{1}$ \\ ${ }^{1)}$ Program Studi Teknik Pertanian, Universitas Hasanuddin Makassar
}

\begin{abstract}
ABSTRAK
Salah satu cara untuk memperbaiki struktur tanah adalah dengan penggunaan bahan organik. Penggunaan bahan organik pada lahan petanian menggunakan aplikator memiliki beberapa kelebihan yaitu menghemat tenaga dan mengefisienkan waktu pengerjaan. Aplikator pupuk organik dirancang khusus untuk menyalurkan pupuk organik ke lahan pertanian utamanya di sekitar tanaman baik di antara tanaman ataupun di sela tanaman dengan kedalaman dan dosis tertentu. Tujuan penelitian ini adalah untuk mengetahui efisiensi dari aplikator pupuk organik pada lahan tanaman hortikultura (melon) dan untuk mengetahui pengaruh pemberian bahan organik menggunakan aplikator terhadap pertunbuhan tanaman melon dan sifat fisik tanah. Untuk mendapatkan kapasitas lapang aplikator dilakukan pengujian pada lahan pertanian dan pengambilan sampel tanah pada awal penelitian dan setelah panen untuk mengetahui sifat fisik tanah serta dilakukan pengukuran pertumbuhan tanaman. Berdasarkan hasil pengujian aplikasi pupuk organik menggunakan aplikator pupuk organik pada lahan tanaman melon diperoleh tingkat aplikasi pupuk organik sebanyak 12 ton/ha, sedangkan kebutuhan tanaman melon sebesar 16 ton/ha sehingga rasio aplikasi pupuk organik terhadap dosis yang diharapkan adalah $3: 4$. Pemberian bahan organik menggunakan aplikator memberikan pengaruh positif terhadap pertumbuhan tanaman melon serta sifat fisik tanah (kadar air dan bulk density).
\end{abstract}

\section{Kata kunci: Aplikator, Bahan Organik, Pertumbuhan, Sifat Fisik Tanah}

\section{PENDAHULUAN}

\section{Latar Belakang}

Peningkatan produktivitas hasil pertanian dari waktu kewaktu menjadi perhatian utama pemerintah, mulai dari penggunaan bibit unggul, penggunaan pupuk serta penggunaan alat dan mesin pertanian atau mekanisasi pertanian. Hal tersebut sangat sulit tercapai karena penggunaan lahan secara intensif akan mengakibatkan menurunnya unsur hara dalam tanah, di tambah lagi dengan penggunaan zat-zat kimia secara berlebihan. Salah satu cara untuk mengembalikan atau memperbaiki struktur tanah tersebut adalah dengan penggunaan bahan alami seperti bahan organik, penggunaan bahan organik akan memberikan keuntungan bagi tanah, tanaman dan lingkungan.
Penggunaan atau pemanfaatan bahan organik di lahan tentunya memerlukan tenaga yang besar terutama pada lahan pertanian yang luas, sehingga untuk menghemat tenaga yang digunakan dan mengefisienkan waktu maka digunakan aplikator. Aplikator pupuk organik ini dirancang khusus untuk menyalurkan pupuk organik kelahan pertanian utamanya disekitar tanaman baik di antara tanaman ataupun di sela tanaman dengan kedalaman dan dosis tertentu, dimana aplikator ini di gandeng menggunakan traktor sebagai sumber penarik. Aplikator ini dapat digunakan untuk beberapa jenis tanaman yang memliki jarak tanam yang hampir sama, salah satunya adalah tanaman melon.

Tanaman melon merupakan jenis tanaman yang dalam kegiatan budidayanya membutuhkan kondisi tanah yang kaya 
akan bahan organik serta drainase yang baik. Pemberian bahan organik pada tanaman melon menggunakan aplikator sangat menguntungkan karena dengan penggunaan alat ini dapat mengatur dosis pemberian bahan organik dan sesuai dengan tempat yang diinginkan. Menurut Safuan (2012), untuk meningkatkan pertumbuhan dan produksi tanaman melon diperlukan pemberian bahan organik dengan dosis 10-15 ton/ha dan pupuk Kaliun 50-150 Kg.

Berdasarkan uraian di atas maka dilakukan penelitian ini untuk mengetahui efisiensi dari penggunaan aplikator pada lahan tanaman melon dan mengetahui pengaruh pemberian bahan organik menggunakan aplikator pupuk organik pada tanaman melon terhadap keragaan tanaman dan sifat fisik tanah.

\section{Tujuan dan Kegunaan}

Tujuan penelitian ini adalah untuk mengetahui efisiensi dari aplikator pupuk organik pada lahan tanaman hortikultura (melon) dan untuk mengetahui pengaruh pemberian bahan organik menggunakan aplikator terhadap pertumbuhan tanaman melon dan sifat fisik tanah.

Kegunaan dari penelitian ini adalah sebagai bahan informasi bagi petani tentang pengaruh pemberian bahan organik terhadap pertumbuhan tanaman hortikultura (melon) dan sifat fisik tanah.

\section{METODE PENELITIAN}

\section{Waktu dan Tempat}

Penelitian ini dilaksanakan pada bulan Oktober sampai Desember 2017. Bertempat di lahan pertanian Desa Parangbaddo, Kecamatan Polongbangkeng Utara, Kabupaten Takalar, Provinsi Sulawesi Selatan. Analisis kadar air tanah di lakukan di Laboratorium Processing, Program Studi Teknik Pertanian, Departemen Teknologi Pertanian.

\section{Alat dan Bahan}

Alat yang digunakan dalam penelitian ini adalah aplikator pupuk organik, traktor roda dua, ring sampel, timbangan digital, timbangan gantung, meteran, patok, oven, dan kamera.

Bahan yang digunakan pada penelitian ini adalah bahan organik (blotong), sampel tanah, dan bibit tanaman melon.

\section{Metode Penelitian}

Penelitian ini terdiri dari beberapa bagian yaitu pengujian lapang aplikator untuk mengetahui efisiensi alat dan pengambilan sampel tanah untuk mengetahui pengaruh pemberian bahan organik, pengambilan sampel tanah ini dilakukan pada awal penelitian dan setelah panen.

1. Uji Lapang Aplikator

a. Menyiapkan alat dan bahan yang akan digunakan

b. Menimbang bahan organik yang akan digunakan

c. Menghubungkan batang penghubung aplikator dengan titik gandeng pada trakror

d. Mengisi bak aplikator dengan bahan organik yang telah ditimbang

e. Mengatur tinggi bukaan pintu pengeluaran aplikator

f. Mengoperasikan aplikator pada lahan, dimana pola pengolahan tanah yang digunkan ialah pola tepi karena lebih efektif dan sesuai dengan kondisi lahan

g. Mencatat waktu yang digunakan selama proses pengoperasian aplikator

2. Pengambilan Sampel Tanah (Awal Penelitian dan Setelah Panen)

a. Menyiapkan alat dan bahan yang akan digunakan

b. Menimbang ring sampel yang akan di gunakan

c. Mengambil sampel tanah pada kedalaman antara 0-10 cm dan $10-20 \mathrm{~cm}$

d. Menimbang sampel tanah

e. Mengulangi prosedur a-d sebanyak 3 kali pada titik yang berbeda masing-masing pada lahan yang 
ISSN: 1979-7362

diberi kompos dan yang tidak di beri kompos.

f. Mengeringkan sampel tanah

g. Menimbang sampel tanah yang telah dikeringkan

3. Pengukuran pertumbuhan tanaman dimana parameter yang di ukur adalah pertambahan panjang batang tanaman dan jumlah daun setiap minggu.

\section{Perhitungan}

a. Menghitung kapasitas kerja lapang teoritis menggunakan persamaan 1

b. Menghitung kapasitas kerja lapang efektif menggunakan persamaan 2

c. Menghitung kadar air tanah menggunakan persamaan 4

d. Menghitung bulk density menggunakan persamaan 5

\section{Bagan Alir Penelitian}

Penelitianinidilakukandenganbaganali rsebagaiberikut:

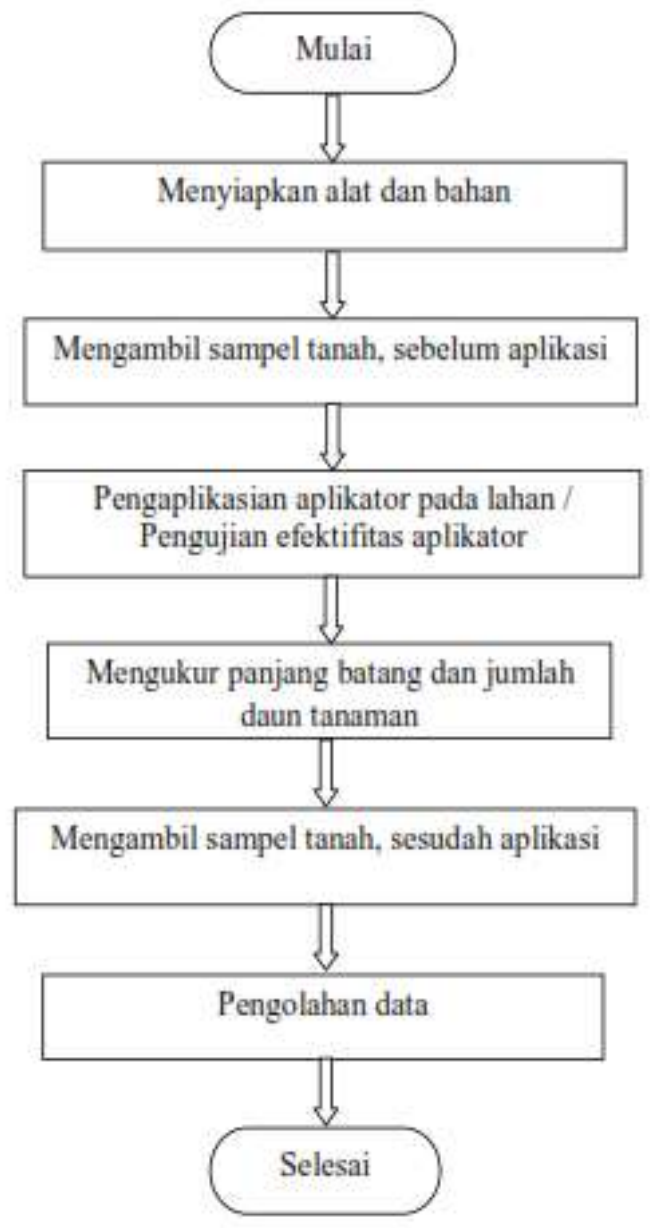

Gambar 1. Bagan Alir Penelitian

\section{HASIL DAN PEMBAHSAN}

\section{Kondisi Lahan}

Lahan tempat penelitian merupakan lahan masyarakat yang terletak di desa Parangbaddo, lahan ini di kelilingi oleh rumah dan kebun masyarakat sehingga lahan tersebut tidaklah terlalu luas. Sebelum dilakukan penelitian tanaman melon, lahan tersebut sudah sering digunakan untuk menanam tanaman (hortikultura) melon maupun tanaman palawija seperti jagung dan beberapa jenis kacang.

Berdasarkan uji Laboratorium yang telah dilakukan di Laboratorium Kimia dan Kesuburan Tanah Jurusan Ilmu Tanah Universitas Hasanuddin. Kandungan bahan organik pada lahan penelitian sebelum pengaplikasian, pupuk organik (blotong) yang digunakan dan kandungan bahan organik pada lahan penelitian setelah pengaplikasian dapat dilihat pada Tabel berikut.

Tabel 1. Unsur Kandungan Tanah pada Lahan Penelitian

\begin{tabular}{lcc}
\hline No & Parameter & Jumlah (\%) \\
\hline 1 & C organik & 1,24 \\
2 & N organik & 0,13 \\
3 & C/N ratio & 10 \\
\hline
\end{tabular}

Kandungan bahan organik pada lahan penelitian masih tergolong sedikit dan dapat diidentifikasi bahwa lahan tersebut tergolong kurang subur dimana unsur $\mathrm{C}$ hanya sebesar $1,24 \%$ dan unsur $\mathrm{N}$ sebesar $0,13 \%$ relatif lebih rendah dari pada kondisi tanah secara umum (kandungan bahan organik sekitar 5\%).

Tabel 2. Unsur Kandungan Bahan Organik yang Digunakan pada Penelitian

\begin{tabular}{lcc}
\hline No & Parameter & Jumlah (\%) \\
\hline 1 & C organik & 2,82 \\
2 & N organik & 0,15 \\
3 & C/N ratio & 19 \\
\hline
\end{tabular}

Bahan organik yang digunakan pada penelitian ini berupa blotong, yang merupakan endapan nira pada proses pembuatan gula. Blotong yang digunakan 
memiliki kandungan $\mathrm{C}$ organik, $\mathrm{N}$ organik dan $\mathrm{C} / \mathrm{N}$ ratio yang dapat dilihat pada Tabel 2. Pemberian blotong pada lahan penelitian dapat meningkatkan kandungan hara pada tanah dan berpengaruh positif pada pertumbuhan tanaman selain itu bahan organik juga dapat meningkatkan kemampuan tanah dalam menahan air. Hal ini sesuai dengan pendapat Leovici (2012), yang menyatakan bahwa Blotong dapat meningkatkan pertumbuhan tanaman karena kemampuan blotong dalam meningkatkan kapasitas menahan air, menurunkan laju pencucian hara, menyediakan unsur hara, memperbaiki drainase tanah, melarutkan fosfor, dan menetralisir pengaruh Al-dd sehingga ketersediaan P dalam tanah lebih tersedia. Tabel 3. Unsur Kandungan Tanah pada Lahan Penelitian Setelah Pengaplikasian

\begin{tabular}{lcc}
\hline No & Parameter & Jumlah (\%) \\
\hline 1 & C organik & 1,58 \\
2 & N organik & 0,14 \\
3 & C/N ratio & 11 \\
\hline
\end{tabular}

Pemberian bahan organik pada lahan tanaman melon yang telah dilakukan memberikan peningkatan terhadap kandungan bahan organik pada lahan tanaman melon. Kandungan bahan organik pada lahan setelah pengaplikasian dapat dilihat pada Tabel 3 dimana unsur $\mathrm{C}$ organik meningkat sebesar $0,34 \%$, N organik meningkat sebesar $0,1 \%$ dan $\mathrm{C} / \mathrm{N}$ ratio meningkat sebesar $1 \%$ dari kondisi awal pada lahan tanaman melon. Berdasarkan data tersebut dapat dilihat bahwa peningkatan kandungan bahan organik setelah dilakukan pengaplikasian menggunakan aplikator mengalami peningkatan yang tidak terlalu besar, namun memberikan pengaruh positif terhadap sifat fisik tanah (kadar air dan bulk density) dan pertumbuhan tanaman melon (panjang tanaman dan jumlah daun). Hal ini sesuai dengan pendapat Leovici (2012), yang menyatakan bahwa blotong dapat meningkatkan pertumbuhan tanaman karena kemampuan blotong dalam meningkatkan kapasitas menahan air, menurunkan laju pencucian hara, menyediakan unsur hara, memperbaiki drainase tanah, melarutkan fosfor, dan menetralisir pengaruh Al-dd sehingga ketersediaan $\mathrm{P}$ dalam tanah lebih tersedia.

\section{Uji Lapang Aplikator}

Pengujian aplikator yang telah dilakukan pada lahan penelitian dengan panjang lintasan $20 \mathrm{~m}$ yang diulangi sebanyak lima kali dibutuhkan waktu rata-rata32,972 suntuk menyelesaikan satu lintasan. Pada pengujian ini aplikator ditarik menggunakan traktor roda 2 yang memiliki tenaga 8,5-10 $\mathrm{Hp}$ dan diperoleh kecepatan rata-rata maju aplikator sebesar $0,606 \mathrm{~m} / \mathrm{s}$ atau 2183,67 m/jam sehingga diperoleh kapasitas lapang teoritis aplikator sebesar $2838,772 \mathrm{~m}^{2} / \mathrm{jam}$ atau 0,284 ha/jam dan kapasitas lapang efektif aplikator sebesar $2403,830 \mathrm{~m}^{2} / \mathrm{jam}$ atau 0,240 ha/jam.

Tabel 4. Data Hasil Pengujian Lapang Aplikator

\begin{tabular}{lc}
\hline \multicolumn{1}{c}{ Keterangan } & Nilai \\
\hline Rata-rata waktu perbaris (s) & 32,972 \\
Rata-rata waktu total (s) & 109,026 \\
$\begin{array}{l}\text { Panjang lintasan (m) } \\
\left.\text { Luas lahan (m }{ }^{2}\right)\end{array}$ & 20 \\
Kecepatan maju (m/s) & 72,8 \\
$\begin{array}{l}\text { Kapasitas lapang teoritis } \\
\text { (Ha/jam) lapang efektif }\end{array}$ & 0,606 \\
$\begin{array}{l}\text { Kapasitas } \\
\text { (Ha/jam) }\end{array}$ & \\
\hline
\end{tabular}

Berdasarkan hasil pengujian aplikasi bahan organik (blotong) menggunakan aplikator pupuk organik pada lahan tanaman melon diperoleh bahwa aplikator pupuk organik dapat mengaplikasikan bahan organik sebesar 12 ton/ha, sedangkan kebutuhan pupuk organik untuk meningkatkan produktifitas tanaman melon dibutuhkan pupuk organik sebanyak 16 ton/ha sehingga rasio aplikasi pupuk organik terhadap dosis pemberian pupuk organik yang diharapkan adalah $3: 4$.

Pola pengolahan tanah yang digunakan pada saat pengujian sangat 
menentukan besar kecilnya waktu yang digunakan selama pengoperasian alat, dimana waktu pengoperasian juga sangat menentukan dalan perhitungan kapasitas lapang teoritis dan kapasitas lapang efektif, salah satu faktor yang menjadi acuan dalam memilih pola pengolahan tanah yang akan digunakan adalah bentuk dan ukuran lahan. Pada penelitian ini digunakan pola tepi karena dianggap lebih efektif, melihat kondisi lahan penelitian yang memanjang dan tidak terlalu luas selain itu pada lahan penelitian juga sudah terdapat bedengan sehingga pengoperasiaan alat langsung mengikuti bedengan yang sudah ada. Hal ini sesuai dengan pendapat Ariesman (2012), yang menyatakan bahwa pada pola tepi pengolahan tanah dilakukan dari salah satu titik sudut lahan. Berputar ke kiri sejajar sisi lahan, sampai ke tengah lahan.Pola ini cocok untuk lahan yang berbentuk bujur sangkar, dan lahan tidak terlalu luas. Diperlukan lahan untuk berbelok pada kedua diagonal lahan.

Pada aplikator pupuk organik yang digunakan hanya terdapat dua titik pengeluaran bahan organik yang berada di antara roda, sehingga penyaluran bahan organik hanya berbentuk garis (sesuai dengan baris tanaman), mengikuti bedengan yang sudah ada dan tidak menutupi seluruh lahan yang dilewati oleh aplikator, dikarenakan masih ada kegiatan pengolahan tanah setelah pemberian bahan organik

\section{Kadar Air}

Gambar 7 dan 8 menunjukkan bahwa selama tiga bulan penelitian pemberian bahan organik dapat meningkatkan kadar air pada lahan yang diberikan bahan organik di bandingkan dengan lahan yang tidak di berikan bahan organik. Pada kedalaman $0 \mathrm{~cm}-10 \mathrm{~cm}$ untuk lahan dengan perlakuan bahan organik mengalami peningkatan kadar air, dimana persentase kadar air awal penelitian sebesar 29,237\% dan setelah panen kadar air meningkat menjadi $30,264 \%$, artinya meningkat sebesar $1,026 \%$. Sedangkan untuk kedalamn $10 \mathrm{~cm}-20 \mathrm{~cm}$ kadar air awal penelitian sebesar $28,411 \%$ dan setelah panen kadar air meningkat menjadi $29,193 \%$, terjadi peningkatan sebesar $0,782 \%$. Jika dibandingkan peningkatan kadar air antara kedalaman $0 \mathrm{~cm}-10 \mathrm{~cm}$ dengan $10 \mathrm{~cm}-20 \mathrm{~cm}$, maka kedalaman 0 $\mathrm{cm}-10 \mathrm{~cm}$ mengalami peningkatan yang lebih besar, ini disebabkan karena sebagian besar bahan organik yang diberikan berada pada permukaan tanah atau pada kedalaman $0 \mathrm{~cm}-10 \mathrm{~cm}$. Hal ini sesuai dengan pendapat Hanafiah (2012), yang menyatakan bahwa bahan organik mempunyai ukuran pori-pori mikro yang jauh lebih banyak dibanding partikel mineral tanah, yang berarti luas permukaan penjerap (kapasitas simpan) air juga lebih banyak, sehingga makin tinggi kadar bahan organik akan makin tinggi kadar dan ketersediaan air tanah.

Kadar air setelah panen pada lahan penelitian yang diberikan perlakuan blotong lebih rendah dibandingkan dengan kadar air pada lahan penelitian tanpa perlakuan. Hal ini disebabkan karena tingkat pertumbuhan tanaman melon pada lahan yang diberikan perlakuan blotong lebih baik (pertumbuhan tanaman lebih panjang dan jumlah daun lebih banyak) mengakibatkan kebutuhan akan air juga lebih besar sehingga tingkat evapotranspirasi juga lebih tinggi. Tingginya nilai evapotranspirasi berakibat pada rendahnya nilai kadar air pada lahan setelah panen dengan perlakuan blotong dibandingkan dengan kadar air pada lahan tanpa perlakuan blotong yang memiliki nilai evapotranspirasi lebih rendah dikarenakan panjang dan jumlah daun tanaman lebih sedikit.

Kadar air awal pada lahan yang tidak diberi bahan organik memiliki persentase kadar air yang lebih tinggi dibandingkan dengan kadar air awal pada lahan yang diberi bahan organaik dikarenakan pada saat pengambilan sampel tanah awal bersamaan dengan musim hujan. Kondisi 
lahan yang belum terolah, kemiringan lahan dan draenase yang belum diperbaiki menyebabkan terjadinya genangan air di sekitar titik pengambilan sampel tanah untuk lahan yang tidak diberikan perlakuan pupuk organik. Hal inilah yang menyebabkan nilai kadar air tanah baik untuk kedalaman $0 \mathrm{~cm}-10 \mathrm{~cm}$ maupun 10 $\mathrm{cm}-20 \mathrm{~cm}$ lebih tinggi dibandingkan dengan kadar air tanah pada lahan yang diberikan perlakuan bahan organik. Hal ini sesuai dengan pendapat Hanafiah (2012), yang menyatakan bahwa faktor iklim dan tanaman juga menentukan kadar dan ketersediaan air tanah. Faktor iklim yang berpengaruh meliputi, curah hujan, temperatur, dan kecepatan angin.

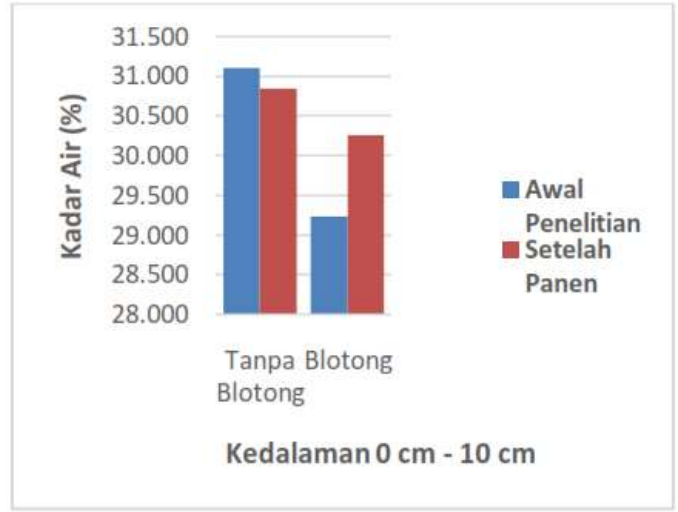

Gambar 2. Grafik Nilai Kadar Air PadaKedalaman $0 \mathrm{~cm}-10 \mathrm{~cm}$

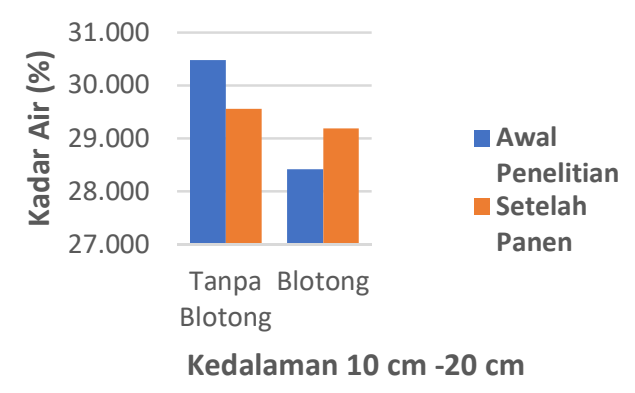

Gambar 3. Grafik Nilai Kadar Air Pada Kedalaman $10 \mathrm{~cm}-20 \mathrm{~cm}$

\section{Bulk Density}

Sifat tanah yang diharapkan pada suatu lahan pertanian adalah memiliki bulk density rendah karena pada kondisi tersebut tanah dapat menyimpan air dalam jumlah yang banyak dan dapat bertahan lama serta memudahkan akar melakukan penetrasi, pada kondisi tanah padat dan mempunyai bulk density tinggi dapat diperkecil dengan cara pemberian bahan organik.

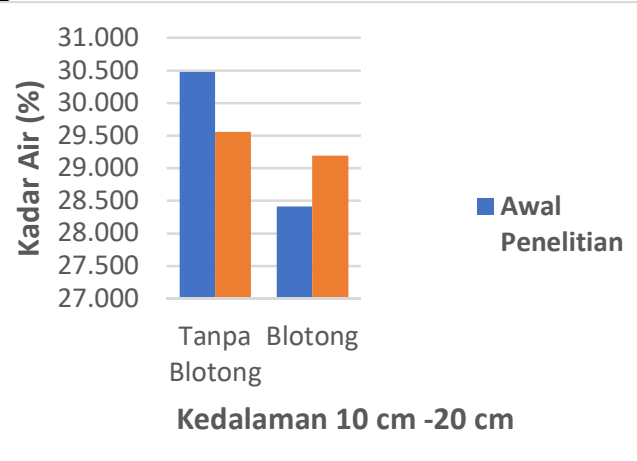

Gambar 4. Grafik Nilai Bulk Density Pada Kedalaman $0 \mathrm{~cm}-10 \mathrm{~cm}$

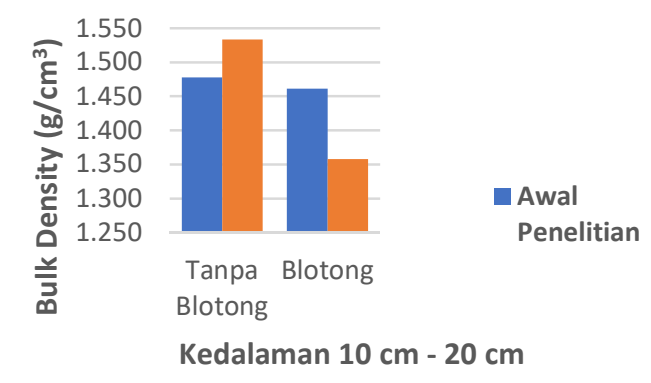

Gambar 5. Grafik Nilai Bulk Density Pada Kedalaman $10 \mathrm{~cm}-20 \mathrm{~cm}$

Hasil penelitian menunjukkan bahwa pemberian bahan organik pada lahan dapat menurunkan nilai bulk density. Pengambilan sampel tanah yang dilakukan setelah panen menunjukkan bahwa pada kedalaman $0 \mathrm{~cm}-10 \mathrm{~cm}$ terjadi penurunan nilai bulk density sebesar $0,063 \mathrm{~g} / \mathrm{cm}^{3}$ dan pada kedalaman $10 \mathrm{~cm}-20 \mathrm{~cm}$ terjadi penurunan nilai bulk density sebesar 0,103 $\mathrm{g} / \mathrm{cm}^{3}$ untuk lahan yang diberi perlakuan blotong. Jika dibandingkan antara kedua kedalaman tersebut, pada kedalaman 10 $\mathrm{cm}-20 \mathrm{~cm}$ mengalami penurunan yang lebih besar, namun jika dibandingkan dengan nilai bulk density pada kedalaman $0 \mathrm{~cm}-10 \mathrm{~cm}$ nilai bulk densitynya lebih kecil dari kedalaman $10 \mathrm{~cm}-20 \mathrm{~cm}$, ini disebabkan karena sebagian besar bahan organik yang diberikan berada pada 
permukaan tanah atau pada kedalaman 0 $\mathrm{cm}-10 \mathrm{~cm}$. Hal ini sesuai dengan pendapat Ginting (2009) yang menyatakan bahwa bulk density merupakan petunjuk tingkat kepadatan tanah, yang menunjukkan bahwa semakin padat suatu tanah maka semakin tinggi nilai bulk density, hal ini menunjukkan bahwa tanah akan semakin sulit dalam meneruskan air, atau semakin sulit akar melakukan penetrasi didalam tanah.

\section{Pertumbuhan Tanaman Melon}

Gambar 6 dan 7 menunjukkan bahwa pemberian bahan organik berpengaruh terhadap pertumbuhan tanaman melon baik dilihat dari pertambahan panjang tanaman maupun jumlah daun, dimana pertumbuhan tanaman melon yang diberi bahan organik lebih baik dari pada pertumbuhan tanaman melon yang tidak di beri bahan organik. Selain itu pemberian bahan organik yang dapat meningkatkan unsur hara pada tanah juga berpengaruh besar terhadap sifat fisik tanah yang meliputi struktur, konsistensi, porositas, daya mengikat air, memperkecil nilai bulk density dan yang tidak kalah penting adalah peningkatan ketahanan terhadap erosi. Hal ini sesuai dengan pendapat Prajananta (2003), yang menyatakan bahwa pertumbuhan tanaman melon akan optimal jika dibudidayakan pada tanah yang banyak mengandung bahan organik serta didukung oleh kondisi lahan yang baik, dengan tingkat kemasaman tanah $(\mathrm{pH}$ tanah) 5,8-7,2.

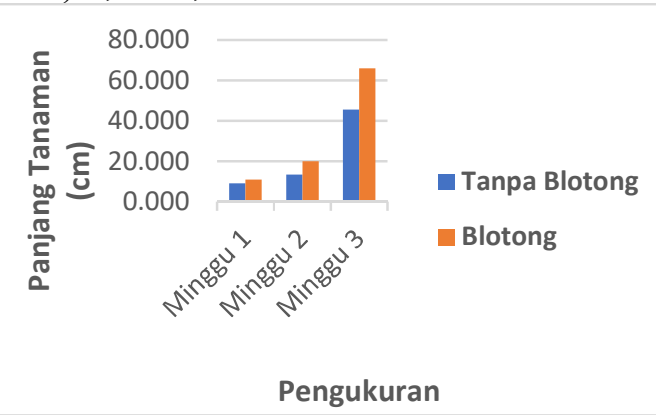

Gambar 6. Grafik Pertumbuhan (Panjang Batang) Tanaman Melon

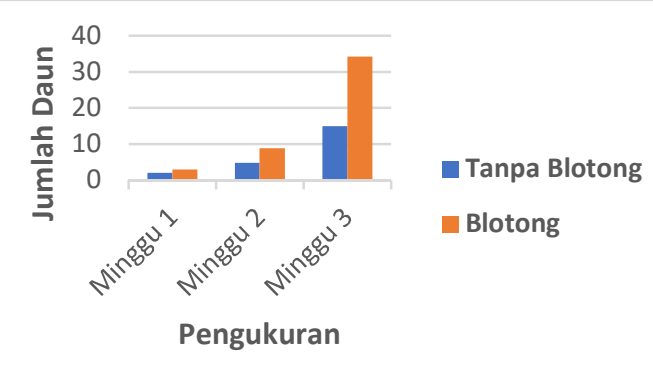

Gambar 7. Grafik Pertumbuhan (Jumlah Daun) Tanaman Melon

Pemberian bahan organik berupa blotong yang kaya akan unsur hara dan kemampuannya dalam menahan air berpengaruh positif terhadap pertumbuhan tanaman melon, hal tersebut ditunjukkan pada grafik pertambahan panjang tanaman dan jumlah daun tanaman melon yang setiap minggunya mengalami peningkatan yang signifikan dan lebih besar dibandingkan dengan tanaman tanpa perlakuan blotong. Dengan meningkatnya massa tanaman melon tentunya akan diiringi dengan meningkatnya kebutuhan air tanaman dan kebutuhan akan unsur hara, sehingga hal tersebut menyebabkan tinnginya nilai evapotranspirasi yang berpengaruh pada kadar air pada lahan setelah tanaman dipanen. Hal ini sesuai denan pendapat Hanafiah (2012), bahwa kadar air tanah merupakan selisih masukan air (water gain) dari presipitasi dikurangi air yang hilang (water loss) melalui evapotranspirasi, aliran permukaan, perkolasi dan rembesan lateral.

\section{PENUTUP}

\section{Kesimpulan}

Berdasarkan penelitian yang telah dilakukan maka diperoleh beberapa kesimpulan sebagai berikut:

1. Hasil pengujian aplikator yang telah dilakukan diperoleh rasio $3: 4$ antara dosis pupuk organik yang teraplikasi dengan dosis kebutuhan pupuk organik tanaman.

2. Penentuan kadar air pada lahan penelitian tidak dapat di tentukan karena adanya pengaruh 
evapotranspirasi oleh tutupan daun tanaman melon.

3. Pemberian bahan organik berhasil menurunkan nilai bulk density pada lahan penelitian dengan perlakuan blotong.

4. Pertumbuhan tanaman melon yang diberikan perlakuan bahan organik lebih baik dibandingkan dengan pertumbuhan tanaman yang tidak diberi 5. bahan organik.

Saran

Sebaiknya pada saat pengujian aplikator keseragaman sebar pupuk organik diukur dan pupuk organik yang digunakan pada penelitian sebaiknya berada dalam kondisi kering sehingga tidak menghambat putaran auger.

\section{DAFTAR PUSTAKA}

Ariesman, 2012. Mempelajari Pola Pengolahan Tanah pada Lahan Kering Menggunakan Traktor Tangan denganBajak Rotari. Universitas Hasanuddin. Makassar

Ginting, Dewi Sagita, 2009. Pendugaan Laju Infiltrasi Menggunakan Parameter Sifat Tanah Pada Kawasan Berlereng. Universitas Sumatra Utara

Halifah, Unik Nur. 2014. Pengaruh Pemberian Pupuk Organik (Blotong) dan Pupuk Anorganik (ZA) Terhadap Tanaman Bawang Merah (Allium ascalonicum L.). Jurnal Produksi Tanaman, Vol. 2. Hal 665-672

Hanafiah, Kemas Ali, 2012. Dasar-dasar Ilmu Tanah. Raja Grafindo Persada. Jakarta.

Iqbal, 2012. Kajian Alat dan Mesin Pengelolaan Serasah Tebu Pada Perkebunan Tebu Lahan Kering PG Takalar. Institut Pertanian Bogor.

Leovici, Helena. 2012. Pemanfaatan Blotong pada Budidaya Tebu
(Saccharum officinarum L.) Di Lahan Kering. Universitas Gajdah Mada. Yogyakarta.

Permatasari, Sartika. 2014. Uji Kinerja Aplikator Kompos Pada Perkebunan Tebu Lahan Kering PG. Takalar. Universitas Hasanuddin. Makassar.

Prajananta. 2003. Melon. Penebar Swadaya. Jakarta.

Redaksi Agromedia, 2008. Cara Praktis Membuat Kompos. PT Agro Media Pustaka. Tangerang

Safuan, L., Bahrun, A. 2012. Pengaruh Bahan Organik dan Pupuk Kalium Terhadap Pertumbuhan dan Produksi Tanaman Melon (Cucumis melo L.). Jurnal Agroteknos 2012, Vol. 2. Hal 69-76

Sinaga, Gunawan., Lukman Adlin Harahap., dan Ainun Rohana. 2015. Studi Banding Kinerja Pengolahan Tanah Pola Tepi dan Pola Alfa pada Lahan Sawah Menggunakan Traktor Tangan Bajak Rotari di Kecamatan Pangkalan Susu. Universitas Sumatra Utara. Medan.

Yuniwati, Murni., Frendy Iskarima, Adiningsih Padulemba. 2012. Oktimasi kondisi proses pembuatan kompos dari sampah organik dengan cara fermentasi menggunakan EM4. Institut Sains \& Teknologi AKPRIND. Yogyakarta. 